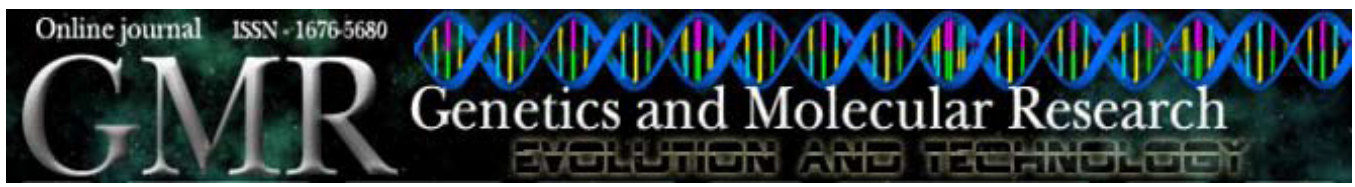

Technical Note

\title{
Isolation and characterization of polymorphic microsatellite loci in the hard-shelled mussel, Mytilus coruscus (Mytilidae)
}

\author{
T.-J. Xu, Y.-N. Sun, Y.-T. Yuan, Z. Liao and R.-X. Wang
}

Key Laboratory for Marine Living Resources and Molecular Engineering, College of Marine Science, Zhejiang Ocean University, Zhoushan, P.R. China

Corresponding author: R.-X. Wang

E-mail: wangrixin1123@126.com

Genet. Mol. Res. 9 (3): 1388-1391 (2010)

Received March 19, 2010

Accepted May 20, 2010

Published July 13, 2010

DOI 10.4238/vol9-3gmr856

\begin{abstract}
Mytilus coruscus is one of the most important cultured species of marine shellfish in China. Using an expressed sequence tag-library and two microsatellite-enriched genomic libraries of $M$. coruscus, we isolated and characterized 12 polymorphic microsatellites in a test population; the number of alleles ranged from three to seven, and the observed and expected heterozygosities ranged from 0.0333 to 0.8571 and from 0.3452 to 0.8267 , respectively. Four loci deviated from Hardy-Weinberg equilibrium. These polymorphic microsatellite loci can be employed in genetic diversity analysis and molecular marker-assisted breeding of $M$. coruscus.
\end{abstract}

Key words: Mytilus coruscus; Microsatellite; Molecular marker 


\section{INTRODUCTION}

The hard-shelled mussel, Mytilus coruscus, is one of the most important marine shellfish species and is widely cultured throughout the coastal areas of the Bohai Sea, Yellow Sea and East Sea in China. Although it is an important commercial shellfish species, little is known about the genetic characteristic of the hard-shelled mussel using the molecular marker technique. The lack of sufficient and polymorphic molecular markers has limited the development of molecular phylogeny, population structure and marker-assisted selective breeding in this shellfish species. Thus, screening for polymorphic microsatellite or other molecular markers is necessary for analyzing genetic information in hard-shelled mussels. In the present study, 12 polymorphic microsatellite DNA markers were developed by expressed sequence tag (EST)cDNA sequences and two microsatellite-enriched genomic libraries were constructed using the fast isolation by the amplified fragment length polymorphism of sequences containing repeats (FIASCO) method (Zane et al., 2002) of hard-shelled mussels. This paper is the first report of polymorphic microsatellite loci in the hard-shelled mussel.

\section{MATERIAL AND METHODS}

A total of 785 ESTs from a cDNA library, which was constructed with our library, had been screened for di-, tri- and tetranucleotide repeats using the SSRhunter software. Fifteen sequences containing simple sequence repeats (SSRs) were identified. We used PRIMER PREMIER 5.0 to design 16 primer pairs that amplified fragments between 221 and $285 \mathrm{bp}$.

Thirty individuals of hard-shelled mussel were collected in the Zhoushan fishing grounds of Zhejiang province, China. Total genomic DNA was extracted from the gills using the TIANamp Genomic DNA Kit (Tiangen) following manufacturer instructions. An enriched partial genomic library for the repeat motif $(\mathrm{AG})_{13}$ and $(\mathrm{CA})_{13}$ using DNA from one individual was constructed essentially following the FIASCO protocol. In brief, genomic DNA was digested using MseI restriction enzyme (MBI) and DNA fragments were selected between 250 and $1000 \mathrm{bp}$ on a $1.2 \%$ agarose gel. These fragments were ligated to adapters and then amplified by polymerase chain reaction (PCR) using MseI-N primers (5'-GATGAGTCCTGAGTAAN-3'). Genomic DNA fragments containing SSRs were then captured by hybridization with $(\mathrm{AG})_{13}$ and $(\mathrm{CA})_{13}$ biotin-labeled probe. Captured fragments were ligated to the pGEM-T vector (Promega) and transformed into DH5 $\alpha$ competent cells according to the standard protocol. Ninetysix positive clones were screened via PCR with SP6/T7 primers, and were sequenced using the ABI 3730 automated sequencer with T7 primer. From the library, 60 clones were successfully sequenced, and 47 sequences contained repeat motifs. Primers for these loci were designed using the PRIMER PREMIER 5.0 software. A total of 32 primer pairs were designed from 32 sequences as the remaining sequences were too close to the cloning site.

Polymorphism at each locus was determined in 30 individuals of hard-shelled mussel. PCR amplifications were carried out in $25-\mu \mathrm{L}$ volumes containing $2.5 \mu \mathrm{L} 10 \mathrm{X}$ PCR buffer, $1.5 \mathrm{mM} \mathrm{MgCl}, 0.2 \mathrm{mM}$ dNTPs, $0.2 \mu \mathrm{M}$ of the forward and reverse primers, and $1.5 \mathrm{U} \mathrm{Taq}$ polymerase (Takara). Cycling conditions consisted of $94^{\circ} \mathrm{C}$ for 4 min followed by 35 cycles of $94^{\circ} \mathrm{C}$ for $40 \mathrm{~s}$, annealing temperature for $45 \mathrm{~s}$ (see Table 1), and $72^{\circ} \mathrm{C}$ for $50 \mathrm{~s}$, followed by 1 cycle of $72^{\circ} \mathrm{C}$ for $5 \mathrm{~min}$ and then holding at $4^{\circ} \mathrm{C}$. PCR amplification was performed on a Bio-Rad Mycycler. Denatured amplified products were separated on $6 \%$ denaturing polyacryl- 
amide (19:1 acrylamide:bis-acrylamide) gels using silver staining (Xu et al., 2009). Denatured pBR322 DNA/MspI molecular weight marker (Tiangen) was used as size standard to identify alleles (Xu et al., 2009). POPGENE32 (Yeh and Boyle, 1997) and ARLEQUIN 3.11 softwares (Schneider et al., 2000) were used to calculate the number of alleles, observed $\left(H_{\mathrm{O}}\right)$ and expected $\left(H_{\mathrm{E}}\right)$ heterozygosities and Hardy-Weinberg equilibrium (HWE) and genotypic linkage disequilibrium, respectively. All results for multiple tests were adjusted using Bonferroni's correction (Rice, 1989).

\section{RESULTS AND DISCUSSION}

Details of the newly developed microsatellite loci and variability measures across 30 individuals of hard-shelled mussel are summarized in Table 1. Four of 16 loci from EST-cDNA sequences and 8 of 32 from the microsatellite-enriched genomic library were successfully amplified and shown to be polymorphic in hard-shelled mussel. The 12 sequences containing a microsatellite locus were deposited in GenBank (GQ888521-GQ888532). No similarity was found between the 12 microsatellites and the published sequences in GenBank. The number of alleles per locus ranged from three to seven, and $H_{\mathrm{O}}$ and $H_{\mathrm{E}}$ ranged from 0.0333 to 0.8571 and from 0.3452 to 0.8267 , respectively. The remaining 24 loci were monomorphic in hard-shelled mussel: four loci (Myco-E6, Myco-3, Myco-6, and Myco-23) deviated from HWE in the sampled population after Bonferroni's correction (adjusted $\mathrm{P}$ value $=0.0042$ ), possibly due to the presence of null alleles or existence of subpopulations; the remaining 8 loci conformed to HWE. Further, null alleles were found in two loci (Myco-E6 and Myco-23), and stuttering was found in two loci (Myco-E6 and Myco-23), detected

Table 1. Characterization of 12 polymorphic microsatellite markers of Mytilus coruscus developed from expressed sequence tag (EST)-cDNA sequences and enriched genomic library.

\begin{tabular}{|c|c|c|c|c|c|c|c|c|}
\hline Locus & $\begin{array}{c}\text { GenBank } \\
\text { accession No. }\end{array}$ & Repeat motif & Primer (5'-3') & Sequence source & $\operatorname{Tm}\left({ }^{\circ} \mathrm{C}\right)$ & Size range (bp) & $\mathrm{N}$ & $H_{\mathrm{O}} H_{\mathrm{E}}$ \\
\hline Myco-E3 & GQ888521 & $(\mathrm{CTC})_{6}$ & $\begin{array}{l}\text { F: GGTCATTGTAGTGCAGTGGGTG } \\
\text { R: ATGCAGTAGGCGGAGGTGC }\end{array}$ & precollagen-NG & 52 & $254-260$ & 3 & $\begin{array}{l}0.5333 \\
0.4525\end{array}$ \\
\hline Myco-E4 & GQ888522 & $(\mathrm{AACA})_{8}$ & $\begin{array}{l}\text { F: AAATACTCCGGTTATGAA } \\
\text { R: ATTACCCTCCCACCTTGA }\end{array}$ & EST-cDNA & 50 & $233-253$ & 5 & $\begin{array}{l}0.4667 \\
0.5040\end{array}$ \\
\hline Мyco-E6 & GQ888523 & $\begin{array}{l}(\mathrm{TGC})_{7} \mathrm{~N}_{30}(\mathrm{TGC})_{11} \\
\mathrm{~N}_{27}(\mathrm{TGC})_{5} \mathrm{~N}_{3}(\mathrm{TGC})_{7}\end{array}$ & $\begin{array}{l}\text { F: TGCACTTGCTGCTGCTCT } \\
\text { R: GCCGGATTAGGAGGTCTAG }\end{array}$ & precollagen-D & 50 & $221-236$ & 3 & $\begin{array}{l}0.0333 \\
0.3650^{*}\end{array}$ \\
\hline Myco-E8 & GQ888524 & $(\text { TGTT })_{6}$ & $\begin{array}{l}\text { F: AAGGTTCAGCAAATTAAG } \\
\text { R: AAAGTTGTTCACAAAGGA }\end{array}$ & EST-cDNA & 50 & $261-285$ & 6 & $\begin{array}{l}0.6000 \\
0.5876\end{array}$ \\
\hline Мyсо-3 & GQ888525 & $(\mathrm{CA})_{10}$ & $\begin{array}{l}\text { F: CACCTTGTGACGCACA } \\
\text { R: CCCCAACACTAAACCTT }\end{array}$ & genomic & 52 & $154-158$ & 3 & $\begin{array}{l}0.7000 \\
0.5045^{*}\end{array}$ \\
\hline Мyco-6 & GQ888526 & $(\mathrm{GT})_{10}$ & $\begin{array}{l}\text { F: CGTCGTGGCGAACATTG } \\
\text { R: TCTGCATCTAGCTCGTAGCG }\end{array}$ & genomic & 50 & $135-143$ & 4 & $\begin{array}{l}0.1786 \\
0.5753^{*}\end{array}$ \\
\hline Myco-8 & GQ888527 & $(\mathrm{GT})_{8}$ & $\begin{array}{l}\text { F: TGCAAGATAGATCGAATAA } \\
\text { R: CTTTTGGTACGCAACAT }\end{array}$ & genomic & 50 & $125-133$ & 5 & $\begin{array}{l}0.5385 \\
0.5219\end{array}$ \\
\hline Myco-11 & GQ888528 & $(\mathrm{TG})_{8}$ & $\begin{array}{l}\text { F: GAAGTCATGCTATAGGGAT } \\
\text { R: TCAACAAATGGGAACAC }\end{array}$ & genomic & 50 & $137-159$ & 6 & $\begin{array}{l}0.8000 \\
0.6584\end{array}$ \\
\hline Мyco-12 & GQ888529 & $(\mathrm{GT})_{11}$ & $\begin{array}{l}\text { F: GATTATTTTCAGTGCCTT } \\
\text { R: CATGTTGGTTACTCCCA }\end{array}$ & genomic & 46 & $158-164$ & 3 & $\begin{array}{l}0.4333 \\
0.5316\end{array}$ \\
\hline Мyсо-14 & GQ888530 & $(\mathrm{GA})_{8}$ & $\begin{array}{l}\text { F: CTACCCGGAAACACGACA } \\
\text { R: CGGCGAAGCATTGACTT }\end{array}$ & genomic & 50 & $156-164$ & 4 & $\begin{array}{l}0.3333 \\
0.3452\end{array}$ \\
\hline Мусо-22 & GQ888531 & $(\mathrm{GA})_{28}$ & $\begin{array}{l}\text { F: TGGAGATGGAAAGAG } \\
\text { R: CTGGAGCCTGCTAC }\end{array}$ & genomic & 50 & $141-147$ & 4 & $\begin{array}{l}0.8571 \\
0.5604\end{array}$ \\
\hline Мyco-23 & GQ888532 & $(\mathrm{CA})_{13}$ & $\begin{array}{l}\text { F: CCGATTCCAAAGGTC } \\
\text { R: AGTTACTGATGCTACTGAGA }\end{array}$ & genomic & 50 & $182-202$ & 7 & $\begin{array}{l}0.2222 \\
0.8267^{*}\end{array}$ \\
\hline
\end{tabular}

$H_{\mathrm{O}}=$ observed heterozygosity; $H_{\mathrm{E}}=$ expected heterozygosity; $\mathrm{N}=$ number of alleles; $\mathrm{Tm}=$ annealing temperature. *Indicates significant deviation from HWE after Bonferroni's correction $(\mathrm{P}<0.0042)$. 
with the MICRO-CHECKER utility (Van Oosterhout et al., 2004) $(\mathrm{P}<0.05)$, but there was no evidence of allelic dropout in any of the loci $(\mathrm{P}<0.05)$. In total, 66 pairwise tests for linkage disequilibrium among 12 loci were non-significant $(\mathrm{P}>0.05$, adjusted $\mathrm{P}$ value $=0.0008)$. These polymorphic microsatellite DNA markers developed in the present study could be useful in molecular markerassisted breeding programs and to evaluate genetic variation in the hard-shelled mussel in the future.

\section{ACKNOWLEDGMENTS}

Research supported by Research Foundation of Zhejiang province (\#2008C22026 and \#20070430), Seeding Grants Programs of Science and Technology Commission Foundation

of Zhejiang Province, and Open Project of Key and Open Laboratory of Marine and Estuarine Fishies, Ministry of Agriculture (\#09-10).

\section{REFERENCES}

Rice WE (1989). Analyzing tables of statistical tests. Evolution 43: 223-225.

Schneider S, Roessli D and Excoffier L (2000). ARLEQUIN: a software for population genetics date analysis, Version 2.000. Genetics and Biometry Laboratory, Department of Anthropology, University of Geneva, Switzerland.

Van Oosterhout C, Hutchinson WF, Wills DPM and Shipley P (2004). MICRO-CHECKER: software for identifying and correcting genotyping errors in microsatellite data. Mol. Ecol. Notes 535-538.

Xu TJ, Shao CW, Liao XL, Ji XS, et al. (2009). Isolation and characterization of polymorphic microsatellite DNA markers in the rock bream (Oplegnathus fasciatus). Conserv. Genet. 10: 527-529.

Yeh FC and Boyle TJB (1997). Population genetic analysis of co-dominant and dominant markers and quantitative traits. Belgian J. Bot. 129: 157.

Zane L, Bargelloni L and Patarnello T (2002). Strategies for microsatellite isolation: a review. Mol. Ecol. 11: 1-16. 